\title{
What's new in karyotyping? The move towards array comparative genomic hybridisation (CGH)
}

\author{
Thomy J. L. de Ravel • Koen Devriendt • \\ Jean-Pierre Fryns • Joris R. Vermeesch
}

Received: 8 January 2007 / Accepted: 27 February 2007 / Published online: 20 March 2007

(C) Springer-Verlag 2007

\begin{abstract}
Molecular karyotyping by array comparative genomic hybridisation (array $\mathrm{CGH}$ ) has doubled the detection rate of pathogenic chromosomal imbalances in patients. This has been possible by increasing the resolution level from the $5 \mathrm{Mb}$ obtained using the conventional karyotype to as low as $100 \mathrm{~kb}$ by array technology. Moreover, the technology revealed that over $12 \%$ of the human genome includes sub-microscopic benign copy number variable regions. These new findings have implications in genetic counselling and patient management.
\end{abstract}

Keywords Molecular karyotyping · Array CGH ·

Comparative genomic hybridisation

$\begin{array}{ll}\text { Abbreviations } \\ \text { Array CGH } & \begin{array}{l}\text { array comparative genomic hybridisation } \\ \text { bacterial artificial chromosome } \\ \text { BAC }\end{array} \\ \begin{array}{ll}\text { cyanide dye } \\ \text { deoxycytidine triphosphate }\end{array} \\ \text { dCTP } & \text { fluorescence in situ hybridisation } \\ \text { FISH } & \text { kilobases } \\ \mathrm{kb} & \text { megabases } \\ \mathrm{Mb} & \text { multiple congenital anomalies } \\ \mathrm{MCA} & \text { mental retardation } \\ \mathrm{MR} & \text { p1 artificial chromosome } \\ \text { PAC } & \text { single nucleotide polymorphism } \\ \text { SNP } & \end{array}$

T. J. L. de Ravel $(\bowtie) \cdot$ K. Devriendt $\cdot$ J.-P. Fryns •

J. R. Vermeesch

Centre for Human Genetics,

University Hospitals Leuven,

Herestraat 49, 3000 Leuven, Belgium

e-mail: Thomy.deRavel@uz.kuleuven.ac.be

\section{Introduction}

Routine chromosome analysis, or karyotyping, has successfully been used for the last 50 years in investigating the cause in patients with mental retardation, specific organ malformations and dysmorphism, whether or not they are part of a syndrome. This has also led to the discovery of genes responsible for various conditions. Standard karyotyping is, however, constrained by the limits of resolution possible by using a microscope. The advent of molecular karyotyping, whereby sub-microscopic copy number changes across the whole genome are evaluated in a single analysis, has greatly increased the detection of pathogenic chromosome imbalances. Whereas standard karyotyping and fluorescence in situ hybridisation (FISH) studies detected chromosome imbalances in $10 \%$ of patients with mental retardation, molecular karyotyping has added an additional $10 \%$ of detection. This is having a great impact on the understanding of pathologies, the counselling of families and patient management [25].

\section{Background}

The human chromosome number of 46 was discovered as recently as 1956 [23], and aneuploidy in 1959 when Lejeune et al. [8] reported trisomy 21 (OMIM 190685) to be the common underlying cause in individuals with the characteristic mental retardation syndrome, also known as Down syndrome. The development of better culture and slide preparations, and the introduction of banding techniques in the 1970s, facilitated the identification of each individual chromosome, and soon, chromosome aberrations were reported in a number of patients with syndromes, as well as in aborted and stillborn foetuses. The occurrence of 
Fig. 1 Standard Giemsa-banded karyotype of a female patient
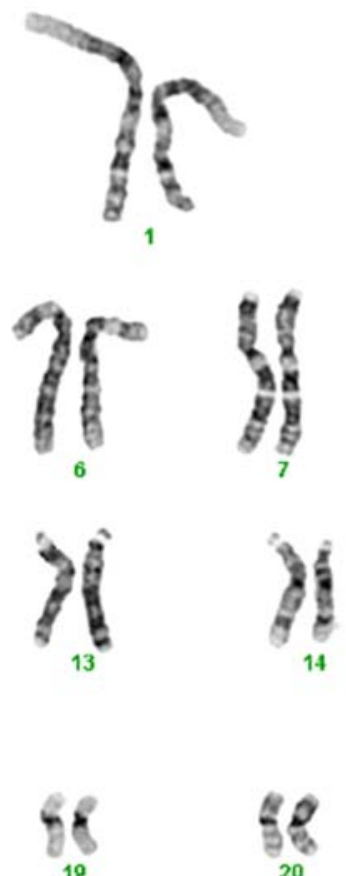

non-pathogenic variations (polymorphisms) was also noted. Present-day standard karyotyping, carried out on dividing cells and using a 10,000× magnification, detects numerical as well as structural chromosome aberrations, such as deletions, duplications, inversions and translocations, as long as they involve at least 5 to 10 million base pairs of DNA (5-10 Mb resolution) (Fig. 1).

Further refinement in the form of fluorescence in situ hybridisation (FISH) uses labelled DNA probes to detect the presence, number and location of small (sub-microscopic) regions of chromosomes, each probe hybridising to a specific already-known DNA sequence. This can confirm the clinical suspicion of known microdeletion syndromes, such as the velocardiofacial (VCFS, 22q11 deletion, OMIM 192430, Fig. 2), William's (7q11.23 deletion, OMIM
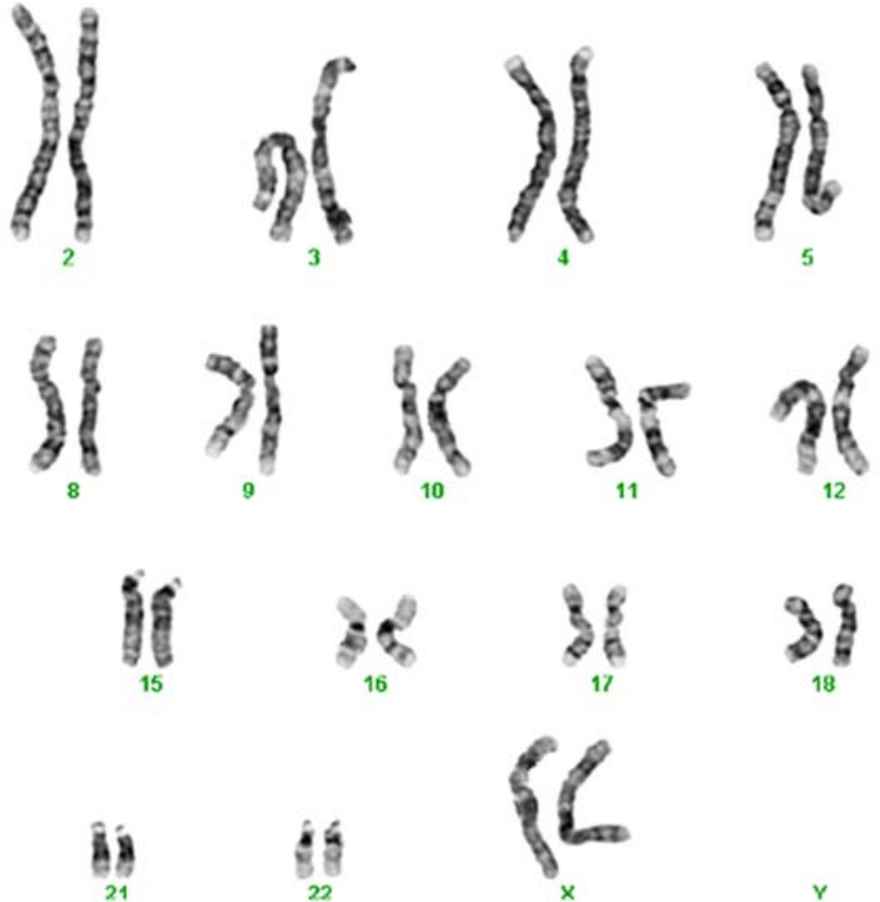

194050) and Prader-Willi (15q11.2-13 deletion, OMIM 176270) syndromes. FISH also detects deletions in the generich subtelomeres which are involved in mental retardation and a number of syndromes, such as the Wolf-Hirschhorn (deletion 4p, OMIM 194190) and chromosome 1p36 deletion (OMIM 607872) syndromes. Using 27 different fluorescent DNA probes simultaneously, "whole chromosome painting" shows re-arrangements at a 1 to $5 \mathrm{Mb}$ resolution but not deletions, duplications and inversions [21].

Tumour tissue was long-known to have chromosome rearrangements, especially deletions or duplications (amplifications). In order to detect these regions (and eventually relate them to prognosis), differentially labelled patient DNA and normal reference DNA were simultaneously hybridised to normal metaphase spreads. Regions of loss
Fig. 2 Fluorescence in situ hybridisation (FISH) analysis using probe $22 \mathrm{q} 11$ (red colour) to demonstrate a normal individual (a) and an individual with a deletion of the chromosome $22 q 11$ region (b). The green fluorescent probe is a control probe on chromosome 22
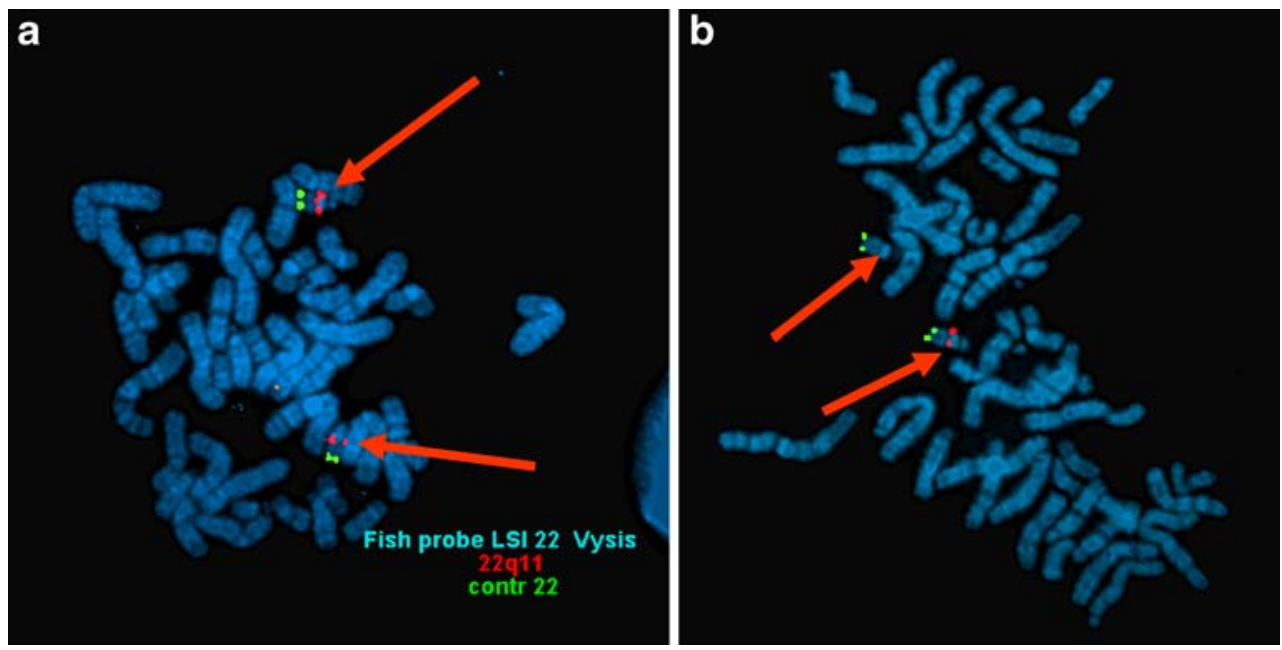
(deletions) and gain (duplications) were seen as changes in the intensities of the two fluorochromes along the chromosomes. This map of DNA sequence copy number as a function of chromosome location was termed comparative genomic hybridisation (CGH) [6]. As chromosomes are used as the template, the resolution is still only $3-5 \mathrm{Mb}$ nowadays. Solinas-Toldo et al. [20] and Pinkel et al. [12] developed array $\mathrm{CGH}$, whereby the hybridisation of the patient DNA takes place on an array of mapped DNA clones instead of metaphase chromosomes. Although chromosomes are no longer visualised under a microscope, the term "molecular karyotyping" is used for this group of techniques since, in analogy to conventional karyotyping, the purpose is the identification of chromosomal imbalances [27].

\section{The array CGH technology}

Genomic DNA of the patient is extracted from peripheral blood lymphocytes, skin fibroblasts or other available tissue and labelled with one fluorescent dye (usually Cy3-labelled dCTPs). The labelled patient DNA, together with an equal amount of control DNA labelled with another fluorescent dye (usually Cy5-labelled dCTPs ), are co-hybridised to a selected set of pre-spotted genomic fragments [26]. The spot intensities are measured at $532 \mathrm{~nm}$ (Cy3) and $635 \mathrm{~nm}$ (Cy5). If the amount of $\mathrm{Cy} 3$ and $\mathrm{Cy} 5$ fluorescent intensities are equal in one spot, this region of the patient DNA is interpreted as being normal/balanced; if a threshold of increased ratio of $\mathrm{Cy} 3$ to $\mathrm{Cy} 5$ is detected, a duplication of the patient DNA is suspected, and inversely if a deletion is present (Fig. 3). In the last three years, studies with $\mathrm{BAC} /$ PAC arrays having a $1-\mathrm{Mb}$ resolution have been the most frequently performed (Table 1). Thus, imbalances of $1 \mathrm{Mb}$ and more can be detected with this technique. Following these initial studies, several technical platforms at increasingly higher resolution have been developed. These include the full tiling BAC arrays, cDNA arrays, oligonucleotide and the SNP arrays, with theoretical resolutions of up to $6 \mathrm{~kb}$. In addition to the information obtained using BAC arrays, a special type of oligonucleotide array can distinguish SNPs, allowing recognition of the parental origin of each DNA copy and enabling the detection of uniparental disomy (UPD); this is important in UPD disorders and cancers. A number of targeted microarrays (e.g. only for the analysis of subtelomeric and microdeletion syndrome regions) are also offered in various centres (reviewed in [25]).

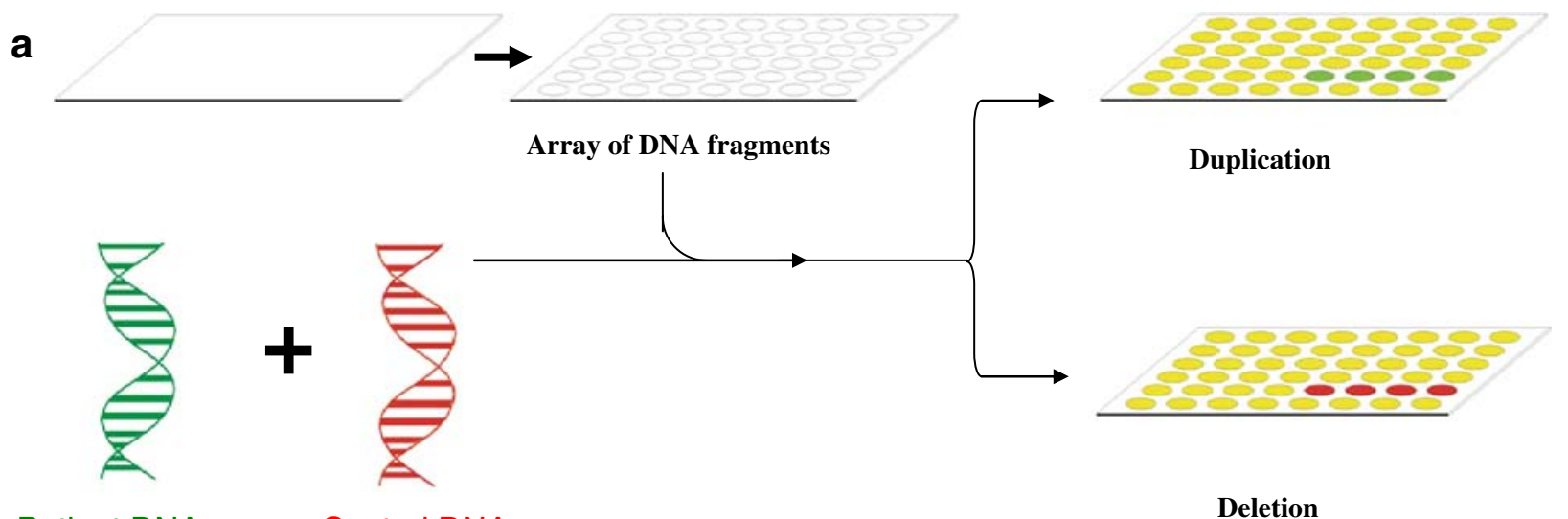

\section{Patient DNA Control DNA}

Deletion

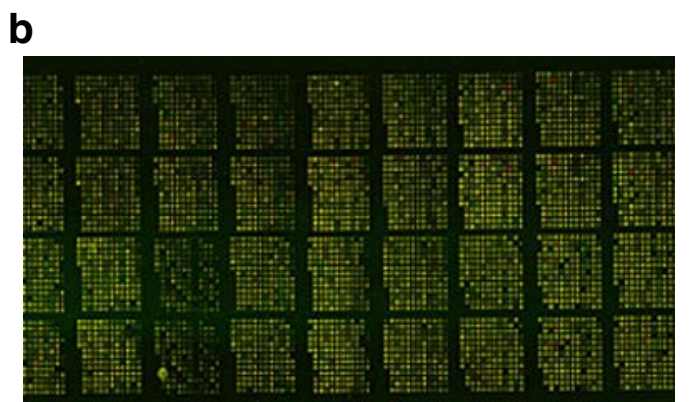

Fig. 3 a The array comparative genomic hybridisation (CGH) technique. b An example of the spotted plate. c Schematic representation of the results of the DNA of a patient with a chromosome 13 deletion co-hybridised against the DNA of a normal control. The DNA clones of chromosomes 1 to 22 and the sex chromosomes are aligned along the $\mathrm{X}$ axis (left to right), whilst the log

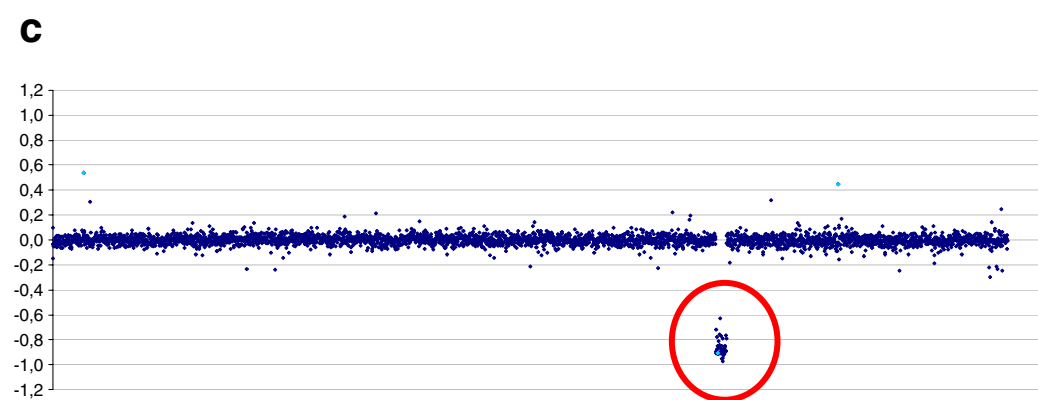

score of the fluorescent analysis obtained for each clone is given along the $\mathrm{Y}$ axis. The deletion (seen in red on the spotted plate in $\mathbf{a}$ and $\mathbf{b}$ ) is represented by negative log scores whilst a duplication (green on spotted plate in a and b) is seen as positive log scores. Thus, the chromosome 13 deletion in this patient is represented by negative log scores of the corresponding clones (shown within the red circle) 
Table 1 Selected studies using molecular karyotyping, the selection criteria and results

\begin{tabular}{|c|c|c|c|c|}
\hline Reference & Selection criteria & Resolution & Positive/total pts & Findings \\
\hline Vissers et al. [28] & MR/dysmorphism & $\begin{array}{l}1 \mathrm{Mb} \\
3,500 \mathrm{BACs}\end{array}$ & $\begin{array}{l}5 / 20 \\
25\end{array}$ & $\begin{array}{l}3 \text { del, } 1 \text { pat } \\
2 \text { dup, } 1 \text { pat }\end{array}$ \\
\hline Shaw-Smith et al. [18] & Learning disability/dysmorphism & $\begin{array}{l}1 \mathrm{Mb} \\
3,431 \text { BACs }\end{array}$ & $\begin{array}{l}12 / 50 \\
24\end{array}$ & $\begin{array}{l}7 \text { del, } 1 \text { pat } \\
5 \text { dup, } 1 \text { pat, } 3 \text { mat }\end{array}$ \\
\hline Menten et al. [11] & $\mathrm{MR} / \mathrm{MCA}$ & $\begin{array}{l}1 \mathrm{Mb} \\
3,431 \mathrm{BACs}\end{array}$ & $\begin{array}{l}28 / 140 \\
20\end{array}$ & $\begin{array}{l}23 \text { del, } 2 \text { pat, } 2 \text { mat } \\
7 \text { dup, } 2 \text { pat, } 1 \text { mat }\end{array}$ \\
\hline Rosenberg et al. [16] & $\mathrm{MR} / \mathrm{MCA}$ & $\begin{array}{l}1 \mathrm{Mb} \\
3,431 \mathrm{BACs}\end{array}$ & $\begin{array}{l}20 / 81 \\
25\end{array}$ & $\begin{array}{l}14 \text { del, } 1 \text { pat, } 1 \text { mat } \\
8 \text { dup, } 1 \text { pat, } 3 \text { mat }\end{array}$ \\
\hline Schoumans et al. [17] & MR/dysmorphism & $\begin{array}{l}1 \mathrm{Mb} \\
2,600 \mathrm{BACs}\end{array}$ & $\begin{array}{l}4 / 41 \\
10\end{array}$ & $4 \mathrm{del}$, de novo \\
\hline Friedman et al. [4] & MR & $100 \mathrm{~kb}$ & $\begin{array}{l}10 / 100 \\
10\end{array}$ & $\begin{array}{l}8 \text { del } \\
2 \text { dup }\end{array}$ \\
\hline de Vries et al. [3] & MR & $\begin{array}{l}100 \mathrm{~kb} \\
32,447 \text { BACs }\end{array}$ & $\begin{array}{l}10 / 100 \\
10\end{array}$ & $\begin{array}{l}7 \text { del, de novo } \\
3 \text { dup, de novo }\end{array}$ \\
\hline Thienpont et al. [22] & Heart anomaly/dysmorphism & $\begin{array}{l}1 \mathrm{Mb} \\
3,431 \mathrm{BACs}\end{array}$ & $\begin{array}{l}18 / 60 \\
30\end{array}$ & $\begin{array}{l}6 \text { del } \\
8 \text { dup } \\
3 \text { del/dup; } 1 \text { mosaic }\end{array}$ \\
\hline
\end{tabular}

Array CGH was carried out except for Friedman et al. [3], where array-based SNP genotyping was performed. The percentage of positive imbalances does not represent the percentage pathogenic results

\section{Clinical applications of array CGH}

Mental retardation and dysmorphism

Eight studies screening individuals with mental retardation, multiple dysmorphic features and normal traditional karyotypes have demonstrated a high diagnostic yield in MCA/MR patients (Table 1). In summary, at the $1-\mathrm{Mb}$ resolution, $20 \%$ to $25 \%$ of selected individuals have deletions or duplications or a combination of both. About half of these are conclusively causal for the disorder. The few studies at $100-\mathrm{kb}$ resolution have also detected about $10 \%$ of pathogenic interstitial aberrations. The chromosome imbalances occur throughout the genome and are often single cases. In order to correlate the aberrant genotypes with the phenotypes worldwide, collaborative databases of results have been set up, e.g. Decipher (http://www.sanger.ac.uk/PostGenomics/decipher/) and Ecaruca (http://www.ECARUCA.net). Two new microdeletion syndromes have, thus far, been delineated using array CGH. An interstitial microdeletion at chromosome $9 \mathrm{q} 22.3$ is associated with a syndrome comprising of macrocephaly, overgrowth, psychomotor retardation and facial dysmorphism [13]. Similarly, a chromosome $17 \mathrm{q} 21.31$ microdeletion associated with a common inversion polymorphism results in a new syndrome comprising of moderate mental retardation, marked hypotonia, a long facies, blepharophimosis, ptosis, pear-shaped nose with a broad tip, long columella, large ears and a broad chin $[7,19]$.

\section{Translocations}

Disruption of dosage-sensitive genes at the translocation breakpoints has long been suspected in patients with mental retardation and/or dysmorphic features. Using array $\mathrm{CGH}$ and sequence analyses, both affected patients and normal apparently balanced translocation carrier-parents were shown to have not only insertions and duplications but also disrupted genes at the site of the translocations. More so, with the aid of array CGH, a significant proportion of translocation patients were found to have complex chromosome re-arrangements both in the chromosomes involved in the translocation as well as in other chromosomes $[1,5]$. The non-translocation-related chromosome imbalance is, in some cases, responsible for the phenotype.

\section{Prenatal investigation}

Array CGH can be carried out on the DNA of single cells, of chorionic villus biopsies and of amniocytes. Due to the complexity in interpreting a complete array (see below), it is foreseen that "targeted arrays" to indicate aneuploidy and known microdeletion/duplication syndromes may be an option in the future [15].

Investigation of cancer

Both numerical and structural imbalances occur in (pre-) malignant cells and more and more of these are being associated with various prognostic factors. Array CGH has 
brought a greater number of these to light and is changing the nature of their diagnoses. For example, using $\mathrm{CGH}$, consistent genetic alterations were shown to be associated with primary cutaneous B-cell lymphomas [10]. However, the investigation of cancers is outside the scope of this review.

\section{Research applications of array CGH}

Gene identification

Traditional chromosome analysis has led to the identification of disease genes after one or more cases with a specific pathology were found to have the same chromosome translocation-breakpoint or deletion. Since molecular karyotyping now enables the rapid detection of small chromosomal imbalances, gene identification has dramatically increased. Dosage-sensitive genes are now detected on screening numerous patients with a specific pathology and the detection of a patient with a microdeletion/duplication locates the region of the genes involved in the pathology. Using this method, for example, the $C H D 7$ gene responsible for autosomal dominantly inherited (with many de novo cases) CHARGE syndrome was identified (reviewed in [29]). Likewise, the B3GALTL gene was found to be mutated in patients with the autosomal recessively inherited Peters Plus syndrome [9]. It is likely that the function of many more genes will be identified in this way.

\section{Genotype-phenotype correlations}

Array CGH is also used at the "full-tiling path" level, where the selected clones overlap, and so, the exact breakpoints of the aberrations can be determined. This is used in the known microdeletion/duplication syndromes which involve multiple genes. The purpose here is to correlate the various components of the phenotype with the loci/genes within the affected chromosomal region. For example, array CGH and FISH analysis permitted the delineation of the $2 \mathrm{q} 32.2 \mathrm{q} 33$ syndrome in four patients, which were then compared to a further nine patients. All of these cases shared a minimal deleted chromosomal region and striking phenotypic similarities. As all patients had a cleft or high palate, it was speculated that hemizygosity of the SATB2 gene within this region may be the underlying cause [24].

\section{Challenges in interpretation}

\section{Copy number variation/polymorphisms}

Numerous regions with non-pathogenic variations in the number of DNA copies (more or less than two copies) are scattered throughout the human genome. Using both array CGH and single nucleotide polymorphism (SNP) genotyping arrays on the 270 individuals of the HapMap collection from ancestry in Europe, Africa and Asia, 1,447 sub-microscopic copy variable regions in the human genome were found [14]. This involves at least $12 \%$ of the genome and includes hundreds of genes in deletions, duplications, insertions and complex multi-site variants. Interestingly, population-specific copy number variations have been detected, which needs to be considered when analysing the results of patients. This is facilitated by access to the Database of Genomic Variants (http://projects.tcag. $\mathrm{ca} / \mathrm{variation} /$ ) and also the results of the HapMap collection mentioned above [14], both of which are visualised in Ensembl (http://www.ensembl.org/).

In the clinical/diagnostic setting, the relevance of these copy number variations is challenging. The finding of an imbalance does not automatically indicate pathogenicity. At present, the following reasoning is followed in the analysis of array CGH results:

- If the imbalance is familial and not a known benign copy number variation, the phenotypic relationship is difficult to interpret

- If the aberration in a patient involves a known microdeletion/duplication syndrome, the imbalance is considered as pathogenic

- If the imbalance has occurred de novo in the patient, and especially if it contains genes with effects compatible with the clinical findings of the patient, this is in support of its pathogenicity but is not absolute proof

In conclusion, the pathogenicity of a chromosomal imbalance in a patient needs to be proved in order to be of use in the management of the patient and in counselling the family as to the implications [2]. To this end, the collaborative efforts through international databases such as Decipher and Ecaruca will, hopefully, with time, permit the detection of similar cases and the determination of the pathogenicity of the individual aberrations.

Thus, when investigating a patient using molecular karyotyping, investigation of the parents and additional family members may often be necessary in order to interpret the results. Without the availability of DNA from parents, molecular karyotyping at the higher $(100-\mathrm{kb})$ resolution is not possible, as the hundreds of polymorphisms may be difficult to interpret.

\section{Concluding remarks}

The introduction of molecular karyotyping has doubled the detection rate of chromosomal imbalances in patients with 
mental retardation and multiple congenital anomalies or dysmorphism and is, therefore, rapidly being introduced as a routine diagnostic technique in genetic diagnostic centres. It is, however, important to carefully select patients to undergo this investigation, as mutations in single-gene disorders will not be detected. Also, the technology is advancing the gene detection rate at a faster pace. The understanding of copy number variations in the human genome is now better understood than ever and its implications in diagnosis and the implications in genetic counselling are being rapidly uncovered. This is challenging the sector into re-thinking the indications for traditional chromosome analysis as opposed to molecular karyotyping.

\section{References}

1. Ciccone R, Giorda R, Gregato G, Guerrini R, Giglio S, Carrozzo $\mathrm{R}$, Bonaglia $\mathrm{MC}$, Priolo $\mathrm{E}$, Laganà $\mathrm{C}$, Tenconi R, Rocchi $\mathrm{M}$, Pramparo T, Zuffardi O, Rossi E (2005) Reciprocal translocations: a trap for cytogenetists? Hum Genet 117(6):571-582

2. de Ravel TJL, Balikova I, Thienpont B, Hannes F, Maas N, Fryns J-P, Devriendt K, Vermeesch JR (2006) Molecular karyotyping of patients with MCA/MR: the blurred boundary between normal and pathogenic variation. Cytogen Genome Res 115(3-4):225-230

3. de Vries BBA, Pfundt R, Leisink M, Koolen DA, Vissers LELM, Janssen IM, van Reijmersdal S, Nillesen WM, Huys EHLPG, de Leeuw N, Smeets D, Sistermans EA, Feuth T, van RavenswaaijArts CMA, van Kessel AG, Schoenmakers EFPM, Brunner HG, Veltman JA (2005) Diagnostic genome profiling in mental retardation. Am J Hum Genet 77(4):606-616

4. Friedman JM, Baross A, Delaney AD, Ally A, Arbour L, Asano J, Bailey DK, Barber S, Birch P, Brown-John M, Cao M, Chan S, Charest DL, Farnoud N, Fernandes N, Flibotte S, Go A, Gibson WT, Holt RA, Jones SJM, Kennedy GC, Krzywinski M, Langlois S, Li HI, McGillivray BC, Nayar T, Pugh TJ, Rajcan-Separovic E, Schein JE, Schnerch A, Siddiqui A, Van Allen MI, Wilson G, Yong S-L, Zahir F, Eydoux P, Marra MA (2006) Oligonucleotide microarray analysis of genomic imbalance in children with mental retardation. Am J Hum Genet 79(3):500-513

5. Gribble SM, Prigmore E, Burford DC, Porter KM, Ng BL, Douglas EJ, Fiegler H, Carr P, Kalaitzopoulos D, Clegg S, Sandstrom R, Temple IK, Youings SA, Thomas NS, Dennis NR, Jacobs PA, Crolla JA, Carter NP (2005) The complex nature of constitutional de novo apparently balanced translocations in patients presenting with abnormal phenotypes. J Med Genet 42 (1):8-16

6. Kallioniemi A, Kallioniemi O-P, Sudar D, Rutovitz D, Gray JW, Waldman F, Pinkel D (1992) Comparative genomic hybridization for molecular cytogenetic analysis of solid tumors. Science 258 (5083):818-821

7. Koolen DA, Vissers LELM, Pfundt R, de Leeuw N, Knight SJL, Regan R, Kooy RF, Reyniers E, Romano C, Fichera M, Schinzel A, Baumer A, Anderlid B-M, Schoumans J, Knoers NV, van Kessel AG, Sistermans EA, Veltman JA, Brunner HG, de Vries BBA (2006) A new chromosome 17q21.31 microdeletion syndrome associated with a common inversion polymorphism. Nature Genet 38(9):999-1001

8. Lejeune J, Gautier M, Turpin R (1959) Études des chromosomes somatiques de neuf enfants mongoliens. C R Acad Sci 248 (11):1721-1722
9. Lesnik Oberstein SAJ, Kriek M, White SJ, Kalf ME, Szuhai K, den Dunnen JT, Breuning MH, Hennekam RCM (2006) Peters Plus syndrome is caused by mutations in B3GALTL, a putative glycosyltransferase. Am J Hum Genet 79(3):562-566

10. Mao X, Lillington D, Child F, Russell-Jones R, Young B, Whittaker S (2002) Comparative genomic hybridization analysis of primary cutaneous B-cell lymphomas: identification of common genomic alterations in disease pathogenesis. Genes Chromosomes Cancer 35(2):144-155

11. Menten B, Maas N, Thienpont B, Buysse K, Vandesompele J, Melotte C, de Ravel T, Van Vooren S, Balikova I, Backx L, Janssens S, De Paepe A, De Moor B, Moreau Y, Marynen P, Fryns J-P, Mortier G, Devriendt K, Speleman F, Vermeesch JR (2006) Emerging patterns of cryptic chromosomal imbalances in patients with idiopathic mental retardation and multiple congenital anomalies: a new series of 140 patients and review of the literature. J Med Genet 43:625-633

12. Pinkel D, Segraves R, Sudar D, Clark S, Poole I, Kowbel D, Collins C, Kuo W-L, Chen C, Zhai Y, Dairkee SH, Ljung B-M, Gray JW, Albertson DG (1998) High resolution analysis of DNA copy number variation using comparative genomic hybridization to microarrays. Nature Genet 20(2):207-211

13. Redon R, Baujat G, Sanlaville D, Le Merrer M, Vekemans M, Munnich A, Carter NP, Cormier-Daire V, Colleaux L (2006) Interstitial 9q22.3 microdeletion: clinical and molecular characterisation of a newly recognised overgrowth syndrome. Eur J Hum Genet 14(6):759-767

14. Redon R, Ishikawa S, Fitch KR, Feuk L, Perry GH, Andrews TD, Fiegler H, Shapero MH, Carson AR, Chen W, Kyung Cho E, Dallaire S, Freeman JL, González JR, Gratacòs M, Huang J, Kalaitzopoulos D, Komura D, MacDonald JR, Marshall CR, Mei R, Montgomery L, Nishimura K, Okamura K, Shen F, Somerville MJ, Tchinda J, Valsesia A, Woodwark C, Yang F, Zhang J, Zerjal T, Zhang J, Armengol L, Conrad DF, Estivill X, Tyler-Smith C, Carter NP, Aburatani H, Lee C, Jones KW, Scherer SW, Hurles ME (2006) Global variation in copy number in the human genome. Nature 444(7118):444-454

15. Rickman L, Fiegler H, Shaw-Smith C, Nash R, Cirigliano V, Voglino G, Ng BL, Scott C, Whittaker J, Adinolfi M, Carter NP, Bobrow M (2006) Prenatal detection of unbalanced chromosomal rearrangements by array CGH. J Med Genet 43(4):353-361

16. Rosenberg C, Knijnenburg J, Bakker E, Vianna-Morgante AM, Sloos W, Otto PA, Kriek M, Hansson K, Krepischi-Santos ACV, Fiegler H, Carter NP, Bijlsma EK, van Haeringen A, Szuhai K, Tanke HJ (2006) Array-CGH detection of micro rearrangements in mentally retarded individuals: clinical significance of imbalances present both in affected children and normal parents. J Med Genet 43(2): 180-186

17. Schoumans J, Ruivenkamp C, Holmberg E, Kyllerman M, Anderlid B-M, Nordenskjöld M (2005) Detection of chromosomal imbalances in children with idiopathic mental retardation by array based comparative genomic hybridisation (array-CGH). J Med Genet 42(9):699-705

18. Shaw-Smith C, Redon R, Rickman L, Rio M, Willatt L, Fiegler H, Firth H, Sanlaville D, Winter R, Colleaux L, Bobrow M, Carter NP (2004) Microarray based comparative genomic hybridisation (arrayCGH) detects submicroscopic chromosomal deletions and duplications in patients with learning disability/mental retardation and dysmorphic features. J Med Genet 41(4):241-248

19. Shaw-Smith C, Pittman AM, Willatt L, Martin H, Rickman L, Gribble S, Curley R, Cumming S, Dunn C, Kalaitzopoulos D, Porter K, Prigmore E, Krepischi-Santos AC, Varela MC, Koiffmann CP, Lees AJ, Rosenberg C, Firth HV, de Silva R, Carter NP (2006) Microdeletion encompassing MAPT at chromosome $17 \mathrm{q} 21.3$ is associated with developmental delay and learning disability. Nature Genet 38(9):1032-1037 
20. Solinas-Toldo S, Lampel S, Stilgenbauer S, Nickolenko J, Benner A, Döhner H, Cremer T, Lichter P (1997) Matrix-based comparative genomic hybridization: biochips to screen for genomic imbalances. Genes Chromosomes Cancer 20(4):399-407

21. Speicher MR, Ballard SG, Ward DC (1996) Karyotyping human chromosomes by combinatorial multi-fluor FISH. Nature Genet 12(4):368-375

22. Thienpont B, Mertens L, de Ravel T, Eyskens B, Boshoff D, Maas N, Fryns J-P, Gewillig M, Vermeesch JR, Devriendt K (2007) Submicroscopic chromosomal imbalances detected by array-CGH are a frequent cause of congenital heart defects in selected patients. Eur Heart $\mathrm{J}$ (in press)

23. Tjio JH, Levan A (1956) The chromosome number of man. Hereditas 42:1-6

24. Van Buggenhout G, Van Ravenswaaij-Arts C, Mc Maas N, Thoelen R, Vogels A, Smeets D, Salden I, Matthijs G, Fryns J-P, Vermeesch JR (2005) The $\operatorname{del}(2)(\mathrm{q} 32.2 \mathrm{q} 33)$ deletion syndrome defined by clinical and molecular characterization of four patients. Eur J Med Genet 48(3):276-289
25. Veltman JA (2006) Genomic microarrays in clinical diagnosis. Curr Opin Pediatr 18(6):598-603

26. Vermeesch JR, Melotte C, Froyen G, Van Vooren S, Dutta B, Maas N, Vermeulen S, Menten B, Speleman F, De Moor B, Van Hummelen P, Marynen P, Fryns J-P, Devriendt K (2005) Molecular karyotyping: array CGH quality criteria for constitutional genetic diagnosis. J Histochem Cytochem 53(3):413-422

27. Vermeesch JR, Rauch A (2006) Reply to Hochstenbach et al. 2006 'Molecular karyotyping'. Eur J Hum Genet 14(10):1063-1064

28. Vissers LELM, de Vries BBA, Osoegawa K, Janssen IM, Feuth T, Choy CO, Straatman H, van der Vliet W, Huys EHLPG, van Rijk A, Smeets D, van Ravenswaaij-Arts CMA, Knoers NV, van der Burgt I, de Jong PJ, Brunner HG, van Kessel AG, Schoenmakers EFPM, Veltman JA (2003) Array-based comparative genomic hybridization for the genomewide detection of submicroscopic chromosomal abnormalities. Am J Hum Genet 73(6):1261-1270

29. Vissers LELM, Veltman JA, van Kessel AG, Brunner HG (2005) Identification of disease genes by whole genome CGH arrays. Hum Molec Genet 14(2):R215-R223 